\title{
A comparative study of the effects of vitamin C, sirolimus, and paclitaxel on the growth of endothelial and smooth muscle cells for cardiovascular medical device applications
}

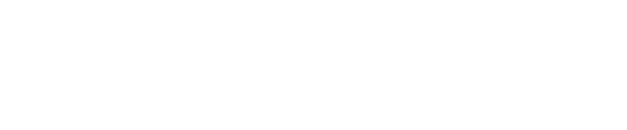

\section{Sandeep Kakade \\ Gopinath Mani}

Biomedical Engineering Program, The University of South Dakota, Sioux Falls, SD, USA
Correspondence: Gopinath Mani Biomedical Engineering Program, The University of South Dakota, 4800 N Career Avenue, Sioux Falls, SD 57I07, USA

Tel + I 6053677773

Email gopinath.mani@usd.edu

\begin{abstract}
Antiproliferative drugs such as sirolimus (SIR) and paclitaxel (PAT) are currently released from stents and vascular grafts to inhibit the growth of smooth muscle cells (SMCs), thereby preventing neointimal hyperplasia. However, these drugs delay or impair the growth of endothelial cells (ECs) on implant surfaces causing late thrombosis. Hence, there is a need to use alternative drugs in these implants to encourage the growth of ECs and to inhibit the growth of SMCs. Vitamin C (L-ascorbic acid [L-AA]) is one such drug which has been shown to encourage EC growth and inhibit SMC growth when orally administered or added directly to the cell cultures. In this research, four sets of in vitro cell culture experiments were carried out to compare the effects of L-AA, SIR, and PAT on the growth of ECs and SMCs under similar conditions, and to compare the effects of different doses of L-AA to determine the optimal dose for promoting maximum EC growth and inhibiting SMC growth. The ECs and SMCs treated with different drugs were characterized for their viability and proliferation, and morphology using the quantitative resazurin assay (as well as qualitative fluorescence microscopy characterization) and phase contrast microscopy, respectively, for up to 7 days. Also, the phenotype of ECs was characterized using immunofluorescence microscopy. Both SIR and PAT significantly inhibited the EC growth while L-AA significantly encouraged EC growth even more than that of the controls with no drugs. Also, L-AA significantly inhibited SMC growth although the inhibitory effect was inferior to that of SIR and PAT. The L-AA dosage study demonstrated that $100 \mu \mathrm{g}$ and $300 \mu \mathrm{g}$ of L-AA showed maximum EC growth after 7 days when compared to other dosages $(1 \mu \mathrm{g}, 500 \mu \mathrm{g}$, and $1000 \mu \mathrm{g})$ of L-AA and controls investigated in this study. Also, the $100 \mu \mathrm{g}$ and $300 \mu \mathrm{g}$ L-AA doses significantly inhibited the SMC growth. Thus, this study demonstrates that L-AA is a promising drug for potential use in stents and vascular grafts, to promote their endothelialization and inhibit neointimal hyperplasia.
\end{abstract}

Keywords: stents, drug-eluting stents, thrombosis, endothelial cells, cardiovascular

\section{Introduction}

Cardiovascular medical devices such as stents and vascular grafts are implanted in millions of patients every year. ${ }^{1,2}$ However, one of the main concerns with these devices, or any other cardiovascular medical device, is the thrombogenicity, which is the tendency of an artificial material in contact with blood to form thrombus (blood clots). ${ }^{3}$ This may have fatal consequences if the thrombus formed obstructs the blood flow to the heart or other vital organs. Hence, endothelialization of cardiovascular medical devices is crucial for preventing thrombosis. ${ }^{3}$ A normal and healthy endothelial cell 
(EC) layer prevents thrombosis by releasing prostacyclin and nitric oxide, which inhibits platelet adhesion, aggregation, and activation, the key events of thrombosis. ${ }^{4}$ Also, the EC surface contains thrombomodulin, a protein which plays a vital role in providing anticoagulant properties to these cells. ${ }^{4}$ Although a variety of materials have been developed in the past to improve the blood compatibility of medical devices, endothelialization is still considered to be the best approach to avoid thrombosis over the long term. ${ }^{3,5}$ Hence, different strategies are currently being developed to promote endothelialization of cardiovascular medical devices. ${ }^{6}$

Currently available drug-eluting cardiovascular stents release antiproliferative drugs such as sirolimus (SIR) and paclitaxel (PAT) to treat neointimal hyperplasia $(\mathrm{NH}){ }^{7} \mathrm{NH}$ is a wound healing response to an arterial injury that occurs during the implantation of stents. ${ }^{8}$ The primary event of $\mathrm{NH}$ is the growth and migration of smooth muscle cells (SMCs) followed by extracellular matrix deposition inside the lumen to occlude the artery. ${ }^{9}$ Although the antiproliferative drugs released from stents inhibit the growth of SMCs to control $\mathrm{NH}$, these drugs also inhibit EC growth. ${ }^{10}$ The impaired or delayed endothelialization of drug-eluting stents is considered to be the primary reason for the occurrence of late stent thrombosis, ${ }^{11}$ a serious complication that can result in heart attack or death. ${ }^{12}$ In a similar way to what occurs with stents, the antiproliferative drugs are also released from vascular grafts to treat NH. ${ }^{13,14}$ PAT-loaded vascular grafts showed significantly delayed endothelialization, ${ }^{13}$ which could potentially cause late thrombosis. Hence, there is a need to deliver drugs from these medical devices which can inhibit the growth of SMCs but also encourage the growth of ECs. Vitamin C (L-ascorbic acid [L-AA]) is one such therapeutic drug which has been shown to inhibit SMC growth and encourage EC growth when orally administered or added directly to the cell culture studies. ${ }^{15,16}$

The long-term goal of our research is to deliver L-AA from stents and vascular grafts to improve their endothelialization, thereby preventing late thrombosis, as well as inhibiting SMC growth and thereby preventing neointimal hyperplasia. As a first step towards this research goal, we have carried out four sets of in vitro cell culture experiments in this study to demonstrate the use of L-AA for encouraging EC growth and inhibiting SMC growth in comparison with other drugs (SIR and PAT) commonly used in stents and vascular grafts. To the best of our knowledge, no prior studies have been carried out on the following: (a) a comparative study of the effects of L-AA, SIR, and PAT on the growth of ECs and SMCs; (b) a comparative study of the effects of different doses of L-AA including $1 \mu \mathrm{g}, 100 \mu \mathrm{g}, 300 \mu \mathrm{g}, 500 \mu \mathrm{g}$, and $1000 \mu \mathrm{g}$ on the growth of ECs and SMCs.

\section{Materials and methods Drugs and chemicals}

Vitamin-C (L-AA, chemical structure shown in Figure 1A), ethanol (200 proof), and sterile-filtered Dulbecco's phosphate buffered saline (DPBS) were purchased from SigmaAldrich (St Louis, MO, USA). SIR (chemical structure shown in Figure 1B) and PAT (chemical structure shown in

A<smiles>O=C1O[C@H]([C@H](O)CO)C(O)=C1O</smiles>

B

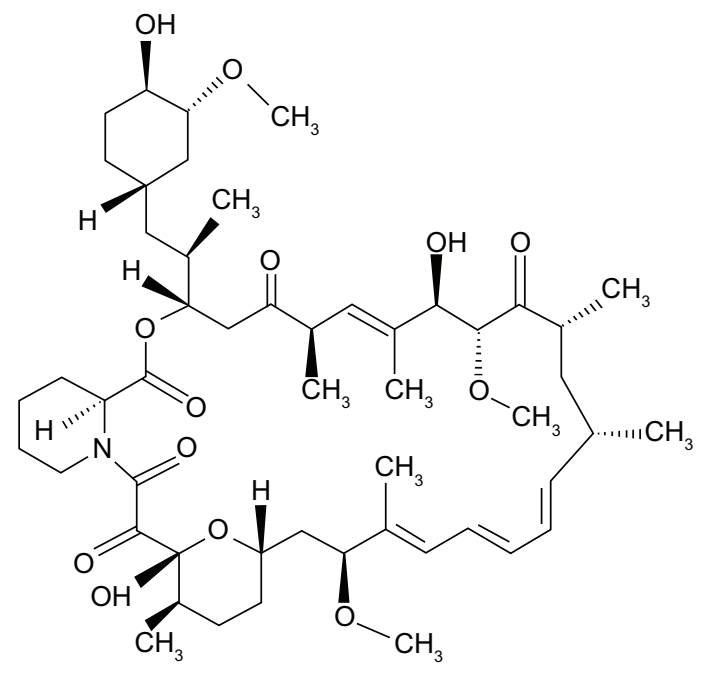

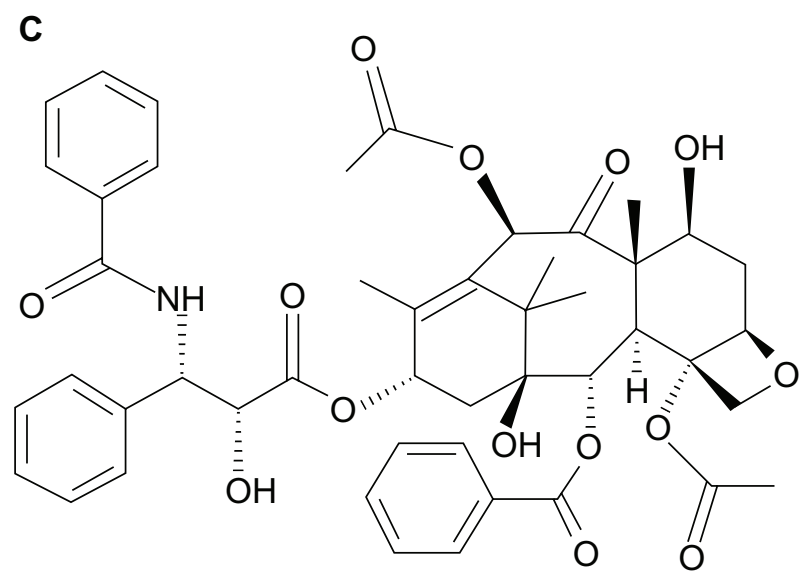

Figure I Chemical structure of L-ascorbic acid (A), sirolimus (B), and paclitaxel (C). 
Figure 1C) were purchased from ChemieTek (Indianapolis, IN, USA). The ethanol was sterile-filtered using a $0.22 \mu \mathrm{m}$ polytetrafluoroethylene syringe filter prior to its use. All drugs were used as received.

\section{Experimental set I: effects of L-AA, SIR, and PAT on EC growth}

In experimental set 1 , the effects of different drugs including L-AA, SIR, and PAT on the growth of ECs were investigated.

\section{Experimental set 2: effects of different doses of L-AA on EC growth}

In experimental set 2 , the effects of different doses of L-AA including $1 \mu \mathrm{g}, 100 \mu \mathrm{g}, 300 \mu \mathrm{g}, 500 \mu \mathrm{g}$, and $1000 \mu \mathrm{g}$ on the growth of ECs were investigated.

\section{Experimental set 3: effects of L-AA, SIR, and PAT on SMC growth}

In experimental set 3 , the effects of different drugs including L-AA, SIR, and PAT on the growth of SMCs were investigated.

\section{Experimental set 4: effects of different doses of L-AA on SMC growth}

In experimental set 4 , the effects of different doses of L-AA including $1 \mu \mathrm{g}, 100 \mu \mathrm{g}, 300 \mu \mathrm{g}, 500 \mu \mathrm{g}$, and $1000 \mu \mathrm{g}$ on the growth of SMCs were investigated.

\section{Preparation of drug solutions}

For experimental sets 1 and 3, the stock solutions of PAT and SIR were prepared in ethanol $(20 \mathrm{mg} / \mathrm{mL})$ while the stock solution of L-AA was prepared in DPBS $(20 \mathrm{mg} / \mathrm{mL})$. These stock solutions were then diluted in EC culture medium for experimental set 1 and SMC culture medium for experimental set 3 to obtain the final concentration of the respective drugs in the working solutions at $100 \mu \mathrm{g} / \mathrm{mL}$. The final ethanol concentration in the working solutions of SIR and PAT was $0.5 \%$ volume per volume (v/v). The final DPBS concentration in the working solution of L-AA was $0.5 \%(\mathrm{v} / \mathrm{v})$.

The stock solution of L-AA in DPBS was diluted in EC culture medium for experimental set 2 , and SMC culture medium for experimental set 4; the working solutions were prepared over a wide range of L-AA doses including $1 \mu \mathrm{g} / \mathrm{mL}$, $100 \mu \mathrm{g} / \mathrm{mL}, 300 \mu \mathrm{g} / \mathrm{mL}, 500 \mu \mathrm{g} / \mathrm{mL}$, and $1000 \mu \mathrm{g} / \mathrm{mL}$. The final DPBS concentration in these working solutions of the different doses of L-AA was 10\% (v/v).

\section{Human aortic endothelial cells and} human aortic smooth muscle cell cultures Human aortic endothelial cells (passage two), EC growth medium, human aortic smooth muscle cells (passage two), and SMC growth medium were all purchased from Cell Applications, Inc (San Diego, CA, USA). The ECs were cultured in the growth medium supplemented with fetal bovine serum $(2 \%)$, basic fibroblast growth factor, heparin, epidermal growth factor, hydrocortisone, penicillin $\mathrm{G}$, streptomycin sulfate, and amphotericin B. The SMCs were cultured in the growth medium supplemented with fetal bovine serum (5\%), basic fibroblast growth factor, heparin, epidermal growth factor, insulin, penicillin $\mathrm{G}$, streptomycin sulfate, and amphotericin B. The cells were cultured in a humidified incubator at $37^{\circ} \mathrm{C}$ with $5 \% \mathrm{CO}_{2}$. Initially, the culture medium was changed after 24 hours. After that, the medium was changed after every 48 hours. When the cells reached $80 \%$ confluence in the flask, they were trypsinized and subcultured for the next passage. The cells from the third to sixth passages were used in these studies.

\section{Addition of drugs to ECs}

Unless otherwise mentioned, a density of $15 \times 10^{3}$ ECs (in $1 \mathrm{~mL}$ of growth medium) for experimental sets 1 and 2 , and a density of $15 \times 10^{3} \mathrm{SMCs}$ (in $1 \mathrm{~mL}$ of growth medium) for experimental sets 3 and 4 was seeded in the wells of 24-well tissue culture-treated polystyrene plates and incubated at $37^{\circ} \mathrm{C}$ in $5 \% \mathrm{CO}_{2}$. The cells were allowed to grow in the wells for 20 hours before the addition of drug. After that, the different drugs (in experimental sets 1 and 3 ) or the different doses of L-AA (in experimental sets 2 and 4) were added to the wells. The cells were exposed to the drugs for 24 hours (for the time point day 1) or 48 hours (for time points day 3 , day 5 , and day 7 ). After the exposure time, the medium was removed and the cells were washed twice with DPBS to remove any unused drug from the wells, followed by the addition of fresh medium. Thereafter, the medium was changed every alternate day with the cells washed twice in DPBS every time that fresh medium was added.

\section{Controls used in the study}

In experimental sets 1 and 3, because the different drugs were exposed to the ECs and SMCs, respectively, in the presence of $0.5 \%$ ethanol (for SIR or PAT) or $0.5 \%$ DPBS (for L-AA) in the culture medium, three different controls were used in this part of the study. Control 1 represents the growth of ECs in experimental set 1 and SMCs in experimental set 3 in the culture medium with no drugs or any solvents (ethanol or 
DPBS) added to the medium. Control 2 represents the growth of ECs in experimental set 1 and SMCs in experimental set 3 in $0.5 \%$ DPBS (with no L-AA added) in the culture medium while the Control 3 represents the growth of ECs in experimental set 1 and SMCs in experimental set 3 in $0.5 \%$ ethanol (with no SIR or PAT added) in the culture medium.

In experimental sets 2 and 4, the different doses of L-AA were exposed to ECs and SMCs, respectively, in the presence of $10 \%$ DPBS in the culture medium. Therefore two different controls were used in this part of the study. Control 1 is the same as the one described in the previous paragraph. Control 2 represents the growth of ECs in experimental set 2 and SMCs in experimental set 4 in 10\% DPBS (with no L-AA) in the culture medium.

\section{Cell viability and proliferation}

The viability and proliferation of cells were measured both quantitatively and qualitatively. Quantitative cell viability and proliferation were measured using the resazurin cell viability assay kit (alamarBlue ${ }^{\circledR}$ ), which was purchased from Biotium, Inc (Hayward, CA, USA). Qualitative cell viability and proliferation were observed using a fluorescence microscopy after staining the live cells with fluorescein diacetate (Sigma-Aldrich).

\section{Quantitative cell viability and proliferation by resazurin assay}

After 1, 3, 5, and 7 days, the medium was removed and a mixture of resazurin solution $(100 \mu \mathrm{L})$ and cell culture media $(900 \mu \mathrm{L})$ was added to each well. The cells were incubated in the solution in the dark at $37^{\circ} \mathrm{C}$ for 6 hours. After that, the solution was orbitally shaken briefly (30 seconds) and the fluorescence of the solution was measured with an excitation wavelength at $530 \mathrm{~nm}$ and an emission wavelength at $590 \mathrm{~nm}$ using a Tecan Infinite ${ }^{\circledR}$ M200 microplate reader (Tecan Group Ltd, Mannedorf, Switzerland) (30 $\mu$ s integration time, gain 25). The fluorescence of the blanks $(100 \mu \mathrm{L}$ resazurin solution and $900 \mu \mathrm{L}$ growth medium in blank wells with no cells) was measured and these values were subtracted from the fluorescence values obtained for the experimental samples. The values presented here are the corrected fluorescence values.

\section{Qualitative cell viability and proliferation by fluorescence imaging}

Initially, a stock solution of fluorescein diacetate (FDA) was prepared in acetone at a concentration of $1 \mathrm{mg} / \mathrm{mL}$. The working solution was prepared by adding $1 \mathrm{~mL}$ of the FDA stock solution to $9 \mathrm{~mL}$ of DPBS. After 1, 3, 5, and 7 days, the medium was removed and the cells were washed twice with DPBS. Then, a mixture of $1000 \mu \mathrm{L}$ of DPBS and $75 \mu \mathrm{L}$ of FDA working solution was added to each well and the cells were incubated in the dark at $37^{\circ} \mathrm{C}$ for 15 minutes. The cells were then imaged using Axiovert $200 \mathrm{M}$ inverted fluorescence microscopy (Carl Zeiss Microscopy, Thornwood, NY, USA).

\section{Cell morphology}

Cell morphology was observed by taking phase contrast images of cells after 7 days using Axiovert $200 \mathrm{M}$ inverted microscopy in the bright field imaging mode.

\section{EC phenotype}

A density of $30 \times 10^{3}$ ECs was used for the phenotype study. After 3 days, the cells were washed twice with DPBS and fixed with $4 \%$ paraformaldehyde for 10 minutes at room temperature. The cells were then washed thrice with DPBS and incubated in blocking buffer (10\% normal goat serum in DPBS) for 20 minutes. After that, the cells were incubated in $1 \mathrm{~mL}$ of primary antibody platelet-endothelial cell adhesion molecule (PECAM-1) (Santa Cruz Biotechnology, Inc, Santa Cruz, CA, USA) diluted 1:50 with 1.5\% goat serum in DPBS for 90 minutes at room temperature. After washing with DPBS (three times for 5 minutes), the cells were incubated in $1 \mathrm{~mL}$ of fluorescein isothiocyanate labeled secondary antibody (goat anti-rabbit IgG-fluorescein isothiocyanate) (Santa Cruz Biotechnology) diluted 1:50 with 1.5\% goat serum in DPBS for 60 minutes at room temperature. The cells were then washed thrice with DPBS for 5 minutes each; the nuclei were then stained by incubating the cells in 4',6-diamidino-2-phenylindole dihydrochloride dye (Santa Cruz Biotechnology) for 5 minutes at room temperature. The cells were then washed with DPBS (three times), and imaged using a Nikon A1 laser scanning confocal microscopy (Nikon Inc, Melville, NY, USA).

\section{Statistical analysis}

For the cell viability and proliferation study of experimental set 1, four samples were used for each of control 1, control 2, control 3, SIR, PAT, and L-AA groups at each time point $(1,3,5$, and 7 days). Thus, 96 samples were used in this part of the study. Similarly, for experimental set 3, 96 samples were used. For experimental set 2, four samples were used for each of control 1, control 2, L-AA (1 $\mu \mathrm{g} / \mathrm{mL})$, L-AA $(100 \mu \mathrm{g} / \mathrm{mL}), \mathrm{L}-\mathrm{AA}(300 \mu \mathrm{g} / \mathrm{mL}), \mathrm{L}-\mathrm{AA}(500 \mu \mathrm{g} / \mathrm{mL})$, and L-AA $(1000 \mu \mathrm{g} / \mathrm{mL})$ groups at each time point $(1,3,5$, and 7 days). Thus, 112 samples were used for this part of the 
study. Similarly, for experimental set 4, 112 samples were used. The experimental data collected were presented as the mean \pm standard deviation. A one-way analysis of variance was used to determine the statistical significance at $P<0.05$. For the qualitative cell viability and proliferation, and cell morphology study, three samples were used for each of the six groups of samples in experimental set 1 and seven groups of samples in experimental set 2 at each time point. Hence, 156 samples were used in this part of the study. Similarly, for experimental sets 3 and 4, 156 samples were used. The fluorescence and phase contrast microscopy images were taken at six to eight different spots on each sample. For the EC phenotype study, two samples were used for each of the groups used in this study at one time point (day 3 ). Hence, 26 samples were used in this part of the study. The immunofluorescence microscopy images were taken at six to nine different spots on each sample.

\section{Results}

\section{Viability and proliferation of ECs for L-AA, SIR, PAT, and controls}

The viability and proliferation of ECs measured by resazurin assay for the three controls and the different drugs used in this study (SIR, PAT, and L-AA) are shown in Figure 2. On day 1, no significant difference in the number of cells was observed between the three controls and L-AA. However, significantly fewer cells were observed for both the antiproliferative drugs SIR and PAT, than for the controls or L-AA. On day 3, the number of cells observed for L-AA was significantly greater than that of all the other samples used in this study including the three controls. SIR and PAT showed no significant increase in the cell growth compared to the number of cells observed for these samples on day 1 . Similar trends were also observed on day 5. On day 7, L-AA showed a maximum number of cells followed by the three controls while the SIR and PAT antiproliferative drugs showed the least number of cells in the group. No significant difference in the number of cells was observed between the three controls at any time point. After 7 days, the EC growth for L-AA was 19 times, 10 times, and 1.5 times greater than that of SIR, PAT, and control 1, respectively. Based on these results, the cell viability and proliferation increased in the following order: $\mathrm{SIR}=\mathrm{PAT}<<$ Control $1=$ Control $2=$ Control $3<$ L-AA. These results demonstrated that L-AA greatly promoted the growth of ECs while the antiproliferative drugs (SIR and PAT) used in currently available stents significantly inhibited the growth of ECs.

The fluorescence microscopy images of FDA-stained ECs for the different samples used in the experimental set 1 are provided in Figure 3. The steady increase in the number of viable cells from one time point to the other was clearly

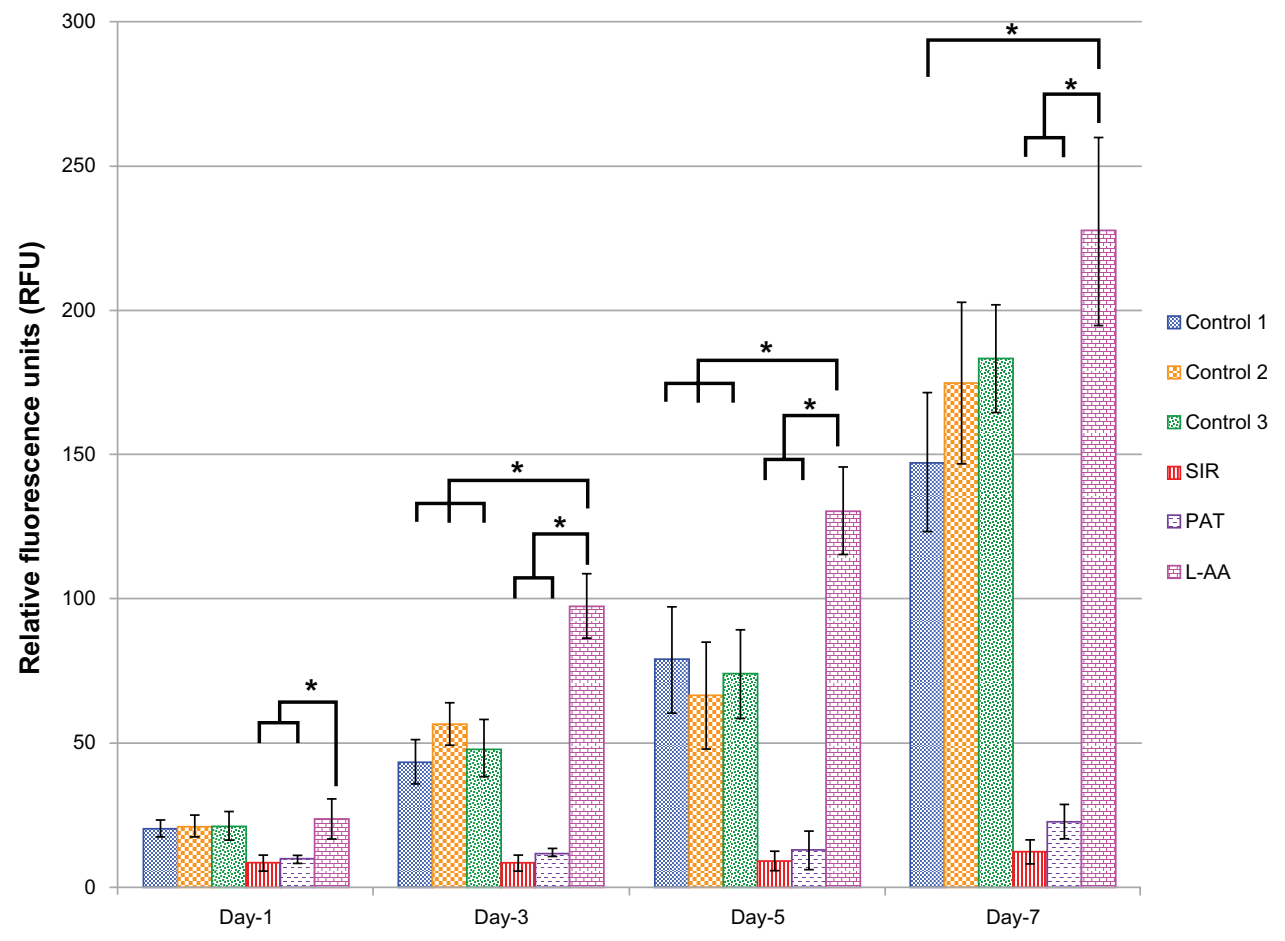

Figure 2 Endothelial cell viability and proliferation for L-ascorbic acid, sirolimus, paclitaxel, and controls.

Notes: * denotes statistical significant differences at $p<0.05$.

Abbreviations: L-AA, L-ascorbic acid; PAT, paclitaxel; SIR, sirolimus. 


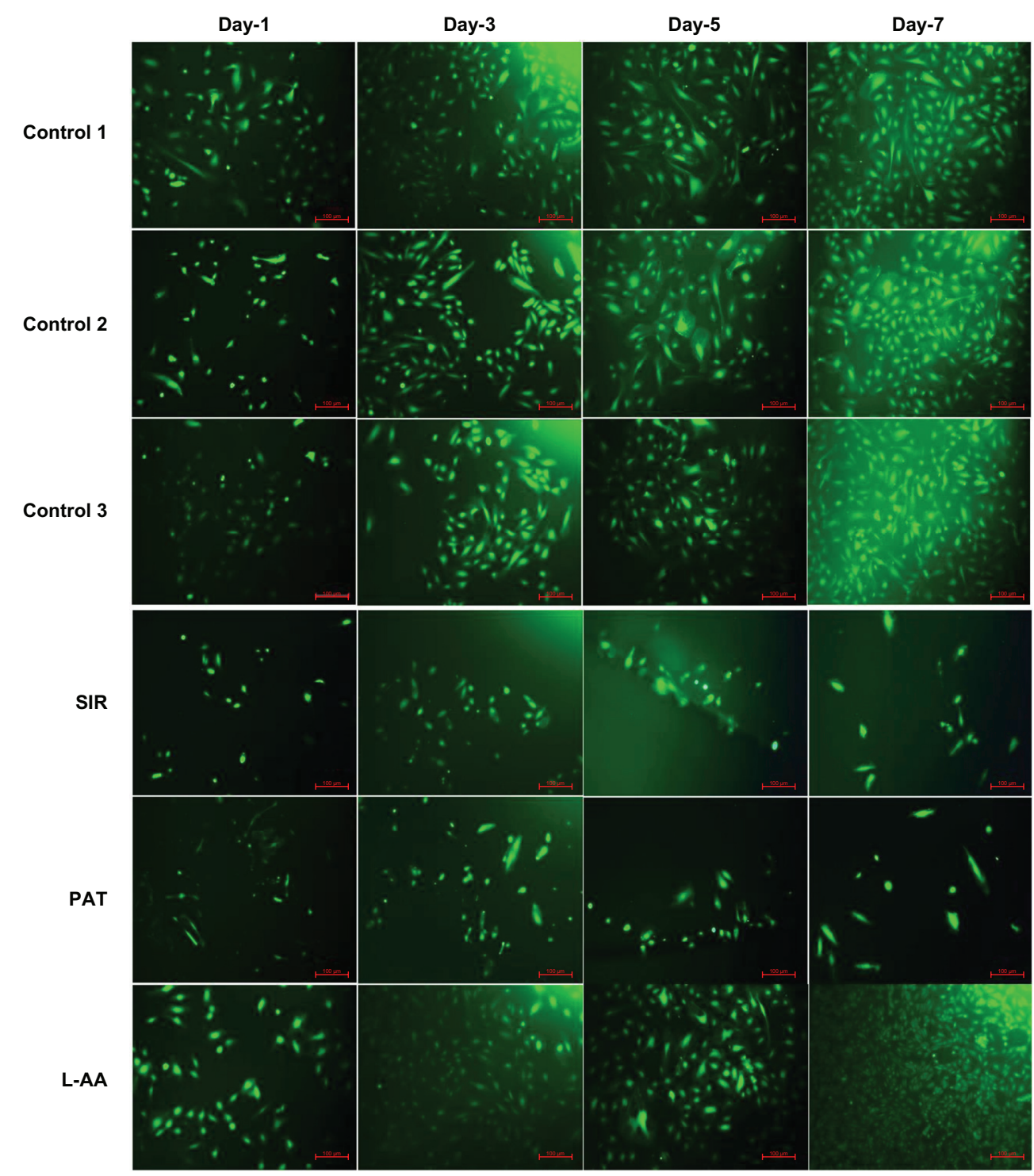

Figure 3 Fluorescence microscopy images of FDA stained ECs for L-AA, SIR, PAT, and controls (scale bar indicates $100 \mu \mathrm{m}$ ). Abbreviations: ECs, endothelial cells; FDA, fluorescein diacetate; L-AA, L-ascorbic acid; PAT, paclitaxel; SIR, sirolimus.

observed in the images of controls and L-AA while no increase in the number of viable cells was observed in the images of SIR and PAT. After 7 days, all the control samples showed $70 \%-80 \%$ confluence while the L-AA treated cells showed $>90 \%$ confluence. SIR and PAT showed very few viable cells with $<20 \%$ confluence. These qualitative results of cell viability and proliferation were in excellent agreement with the quantitative assessment (resazurin data) provided in the above paragraph.

\section{Morphology of ECs for L-AA, SIR, PAT, and controls}

The phase contrast images taken after 7 days of cell growth for the different samples used in experimental set 1 are provided in Figure 4. The ECs showed spreading morphology with characteristic polygonal shape for all three controls (Figure 4A-C) and L-AA (Figure 4F). However, the cells showed an uncharacteristic oval or round shape with no spreading morphology for SIR (Figure 4D) and PAT (Figure 4E). These results showed that the characteristic morphological features of ECs were well maintained for L-AA and controls while such features were not present in the cells treated with SIR or PAT.

\section{Phenotype analysis of ECs for L-AA, SIR, PAT, and controls}

Platelet endothelial cell adhesion molecule-1 (PECAM-1) is an adhesion protein present on the EC membrane. 

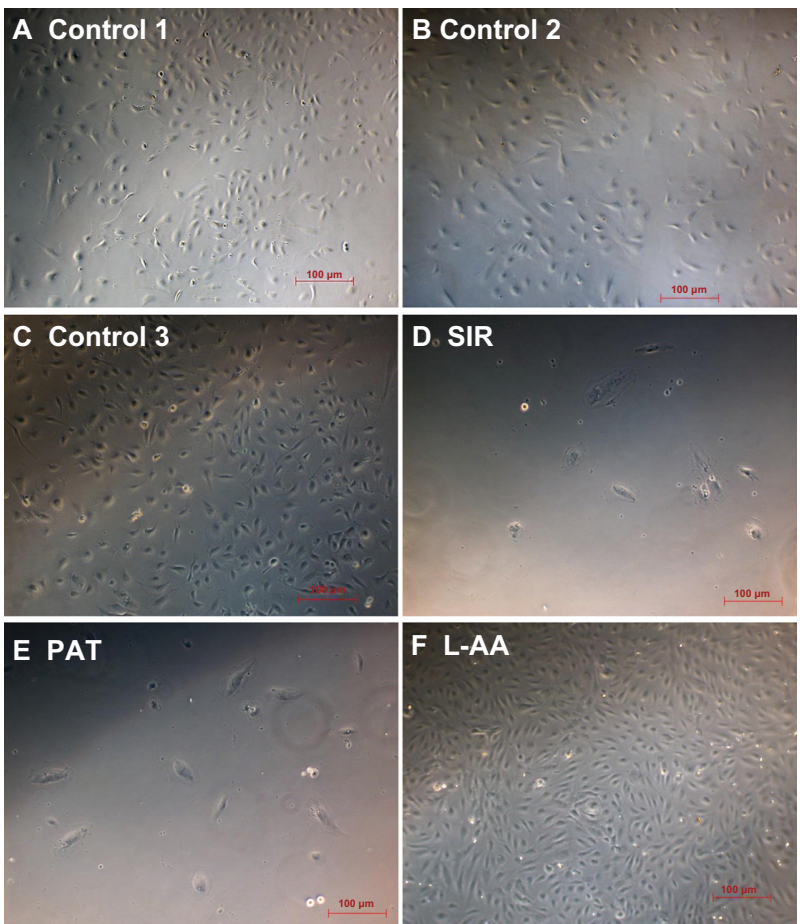

Figure 4 Phase contrast images of ECs for L-AA, SIR, PAT, and controls (A-F) (scale bar indicates $100 \mu \mathrm{m}$ ).

Abbreviations: ECs, endothelial cells; L-AA, L-ascorbic acid; PAT, paclitaxel; SIR, sirolimus.

PECAM-1 is characteristically expressed by ECs and is involved in regulating the adhesion of EC-EC and ECleukocytes. ${ }^{17}$ A stronger expression of PECAM-1 has been attributed to the endothelialization property ${ }^{18}$ while its weaker expression has been attributed to possible cell damage. ${ }^{19}$ In this study, the expression of PECAM-1 on all the controls and the cells treated with different drugs was confirmed by immunofluorescence microscopy (Figure 5; arrows in the images show PECAM-1 expression - bright green staining at the cell surface). The expression of PECAM-1 was stronger for L-AA (Figure 5F) and the three controls (Figure 5A-C). No qualitative difference in the expression of PECAM-1 was observed between the L-AA treated cells and the three controls. However, the expression was weaker for SIR (Figure 5D) and PAT (Figure 5E). These results suggest that the ECs preserved their phenotype and showed excellent endothelialization properties for L-AA and the controls while the cells showed poor endothelialization properties for SIR and PAT.

\section{Viability and proliferation of ECs for the different doses of L-AA and controls}

Figure 6 shows the EC viability and proliferation for the five different doses $(1,100,300,500$, and $1000 \mu \mathrm{g})$ of L-AA
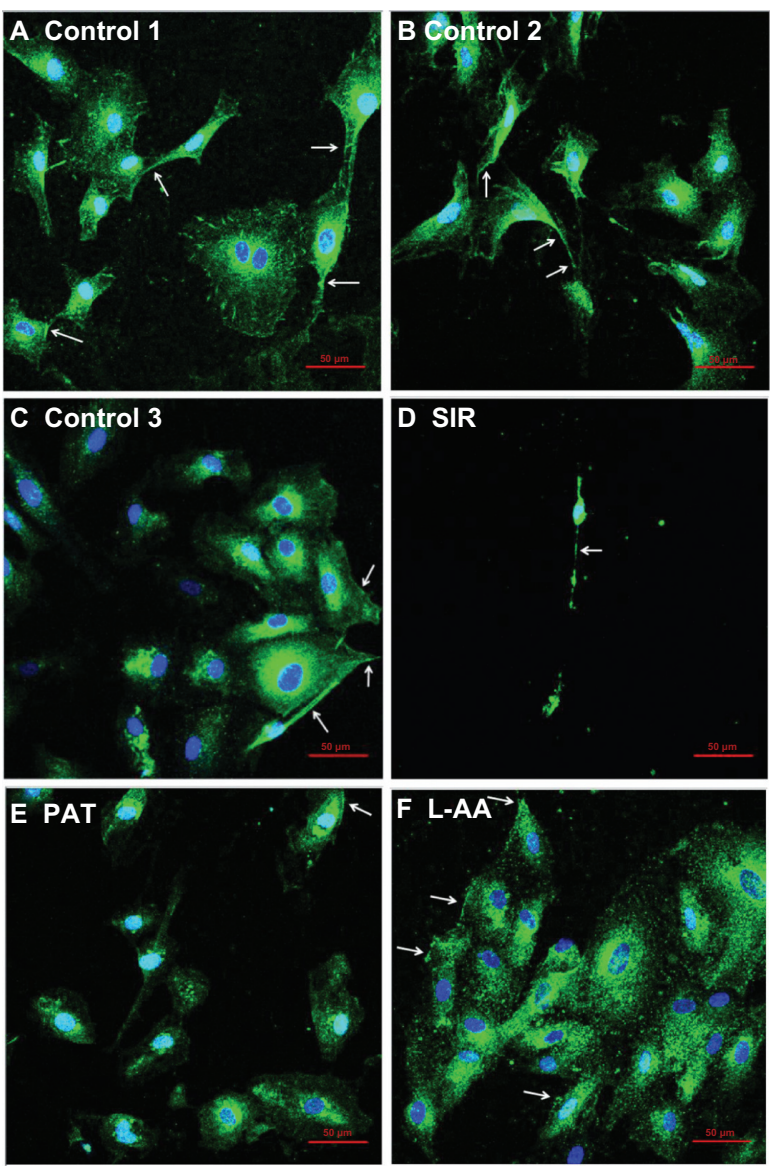

Figure 5 Immunofluorescence microscopy images of ECs for L-AA, SIR, PAT, and controls (A-F) (scale bar indicates $50 \mu \mathrm{m}$ ).

Abbreviations: ECs, endothelial cells; L-AA, L-ascorbic acid; PAT, paclitaxel; SIR, sirolimus.

and the two controls of experimental set 2. On day 1 , no significant differences in the number of cells were observed between the different doses of L-AA and the controls. On day 3 , the number of cells observed for the $100 \mu \mathrm{g} \mathrm{L-AA}$ dose was significantly greater than that of the controls and all the other L-AA doses except the $300 \mu \mathrm{g}$ dose. On day 5, the L-AA doses $100 \mu \mathrm{g}, 300 \mu \mathrm{g}$, and $500 \mu \mathrm{g}$ showed a significantly greater number of cells, compared to controls and the other L-AA doses $1 \mu \mathrm{g}$ and $1000 \mu \mathrm{g}$. On day 7, the doses $100 \mu \mathrm{g}$ and $300 \mu \mathrm{g}$ showed the maximum number of cells among the different groups and were significantly greater than that of any of the controls and all the other doses used in this study. No significant difference in the number of cells was observed between $100 \mu \mathrm{g}$ and $300 \mu \mathrm{g}$ doses. Also, no significant difference in the number of cells was observed between the controls and the L-AA doses $1 \mu \mathrm{g}$ and $500 \mu \mathrm{g}$. The $1000 \mu \mathrm{g}$ dose showed the least number of cells among the different groups used in this study. Based on these results, the viability and proliferation of ECs for the different doses 


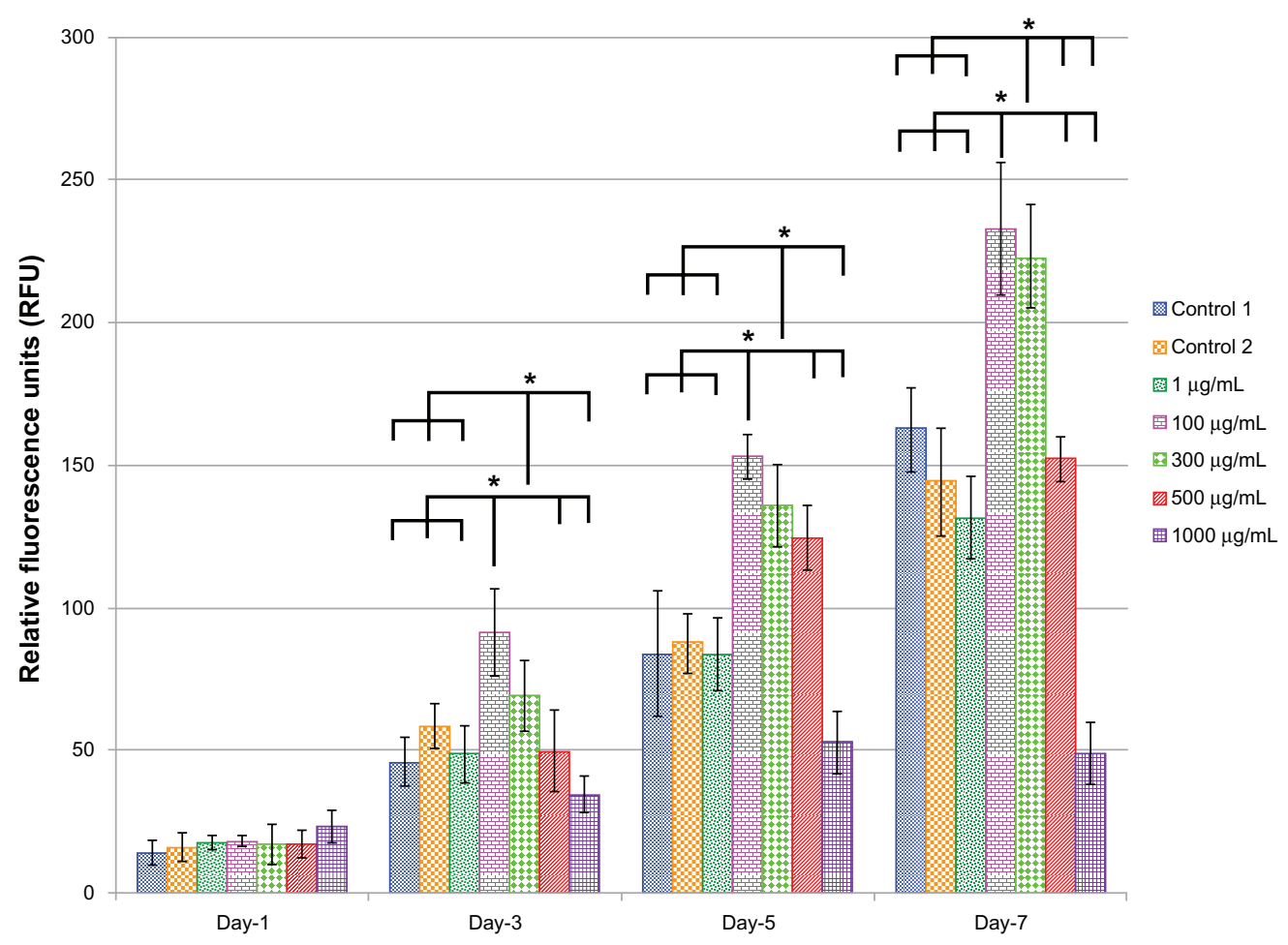

Figure 6 Endothelial cell viability and proliferation for the different doses of L-ascorbic acid. Notes: * denotes statistical significant differences at $p<0.05$.

of L-AA increased in the following order $1000 \mu \mathrm{g}<1 \mu \mathrm{g}=$ Control $1=$ Control $2=500 \mu \mathrm{g}<<300 \mu \mathrm{g}=100 \mu \mathrm{g}$.

The fluorescence microscopy images of FDA-stained ECs for the different doses of L-AA and the controls used in the experimental set 2 are provided in Figure 7. An increase in the number of viable cells from one time point to the other was observed for the controls and all the L-AA doses except the $1000 \mu \mathrm{g}$ dose. After 7 days, the cells treated with $100 \mu \mathrm{g}$ and $300 \mu \mathrm{g}$ doses showed greater than $90 \%$ confluence while the controls and the cells treated with $1 \mu \mathrm{g}$ and $500 \mu \mathrm{g}$ doses showed $\sim 80 \%$ confluence. For the $1000 \mu \mathrm{g}$ dose, the cells were only $\sim 30$ confluent. These qualitative results were in excellent agreement with the quantitative resazurin data presented in the previous paragraph. Thus, these results demonstrated that the $100 \mu \mathrm{g}$ and $300 \mu \mathrm{g}$ doses of L-AA greatly favor the growth of ECs while the growth of cells for the $1 \mu \mathrm{g}$ and $500 \mu \mathrm{g}$ doses was equivalent to that of the controls, and the $1000 \mu \mathrm{g}$ dose inhibited cell growth.

\section{Morphology of ECs for the different doses of L-AA and controls}

The phase contrast microscopy images of ECs after 7 days of growth for the different doses of L-AA and controls are provided in Figure 8. The two controls (Figure 8A and B) and the L-AA doses such as $1 \mu \mathrm{g}, 100 \mu \mathrm{g}, 300 \mu \mathrm{g}$, and $500 \mu \mathrm{g}$ (Figure 8C-F) showed spreading EC morphology with its characteristic polygonal shape. In the $1000 \mu \mathrm{g}$ dose (Figure 8G), although the cells were spreading, they showed an elongated shape. These results suggested that the L-AA doses ranging from $1 \mu \mathrm{g}$ to $500 \mu \mathrm{g}$ did not alter the morphological features of ECs while the high dose such as $1000 \mu \mathrm{g}$ can alter the shape of ECs.

\section{Phenotype analysis of ECs for the different doses of L-AA and controls}

Immunofluorescent microscopy confirmed the expression of PECAM-1 for the two controls and the five different doses of L-AA (Figure 9; arrows in the images show PECAM-1 expression - bright green staining at the cell surface). The PECAM-1 expression was strong for all the groups used in this experimental set and no qualitative differences in the expression were observed between the different groups.

\section{Viability and proliferation of SMCs for L-AA, SIR, PAT, and controls}

The viability and proliferation of SMCs measured by resazurin assay for the three controls and the different 


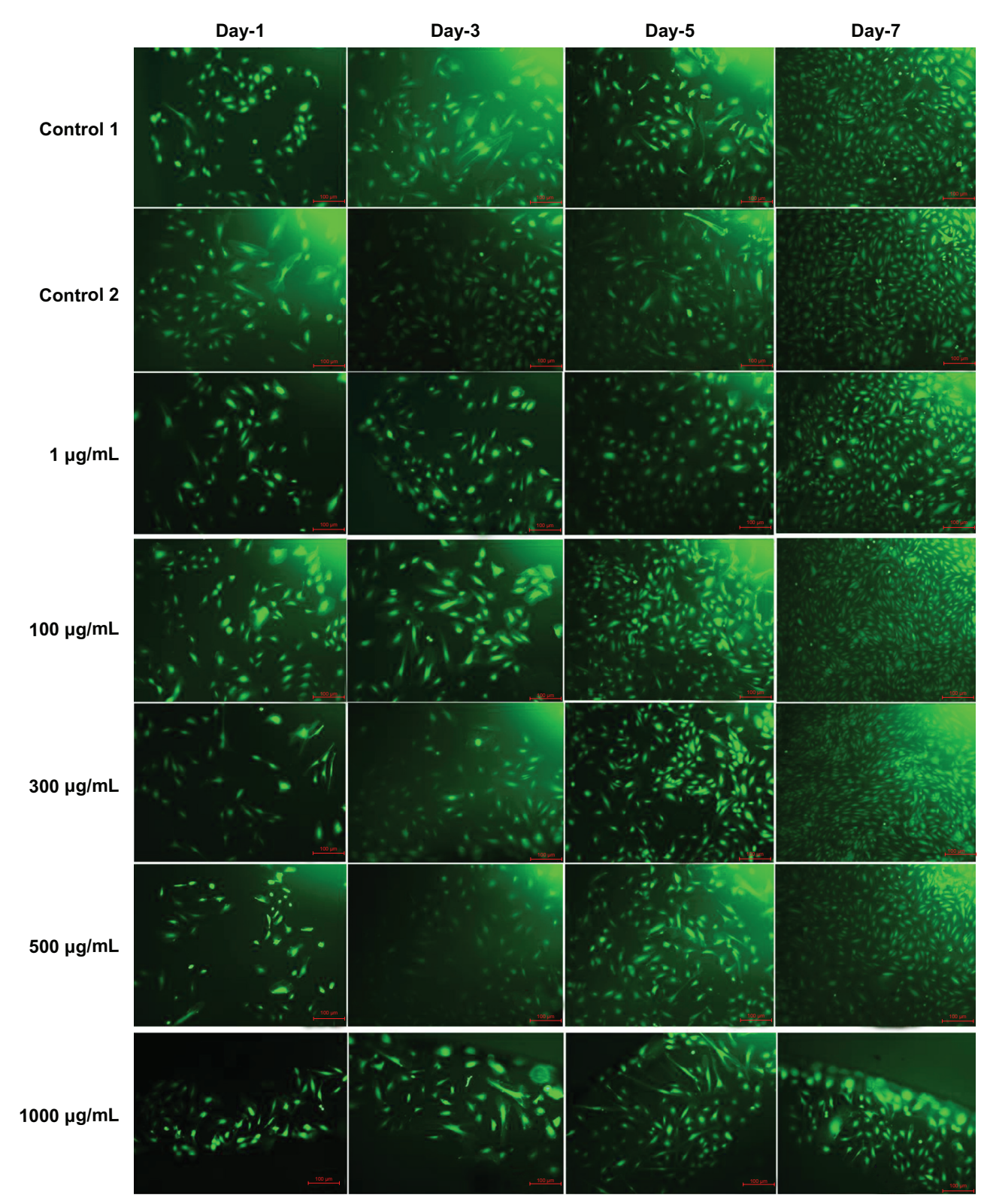

Figure 7 Fluorescence microscopy images of fluorescein diacetate-stained endothelial cells for the different doses of L-ascorbic acid (scale bar indicates $100 \mu \mathrm{m}$ ).

drugs (L-AA, SIR, and PAT) used in this study are shown in Figure 10. On day 1, all three drugs L-AA, SIR, and PAT showed significantly fewer cells than in Control 1. On day 3, the drugs L-AA, SIR, and PAT significantly inhibited cell growth and showed fewer cells than all three controls. Also, at this time point, no significant difference in the number of cells was observed between L-AA, SIR, and PAT. A similar trend was observed on day 5. However, SIR and PAT showed fewer cells than L-AA. Similar results were observed on day 7. Based on these results, SMC viability and proliferation decreased in the following order: Control $1=$ Control $3>$ Control $2>>$ L-AA $>$ SIR $=$ PAT. Thus, these results demonstrated that L-AA significantly inhibited the growth of SMCs although the inhibitory effect was inferior to that of SIR and PAT.

The fluorescence microscopy images of FDA stained SMCs for the different samples used in the experimental set 3 are provided in Figure 11. These images showed that the cells were significantly proliferated on all three controls from one time point to the other, while cell growth was significantly inhibited for L-AA, SIR, and PAT. After 7 days, all control samples showed $>90 \%$ confluence while the L-AA treated cells showed 50\%-60\% confluence. SIR and PAT showed very few viable cells with $\sim 20 \%$ confluence. These qualitative results were in agreement with the quantitative assessment provided in the above paragraph. 


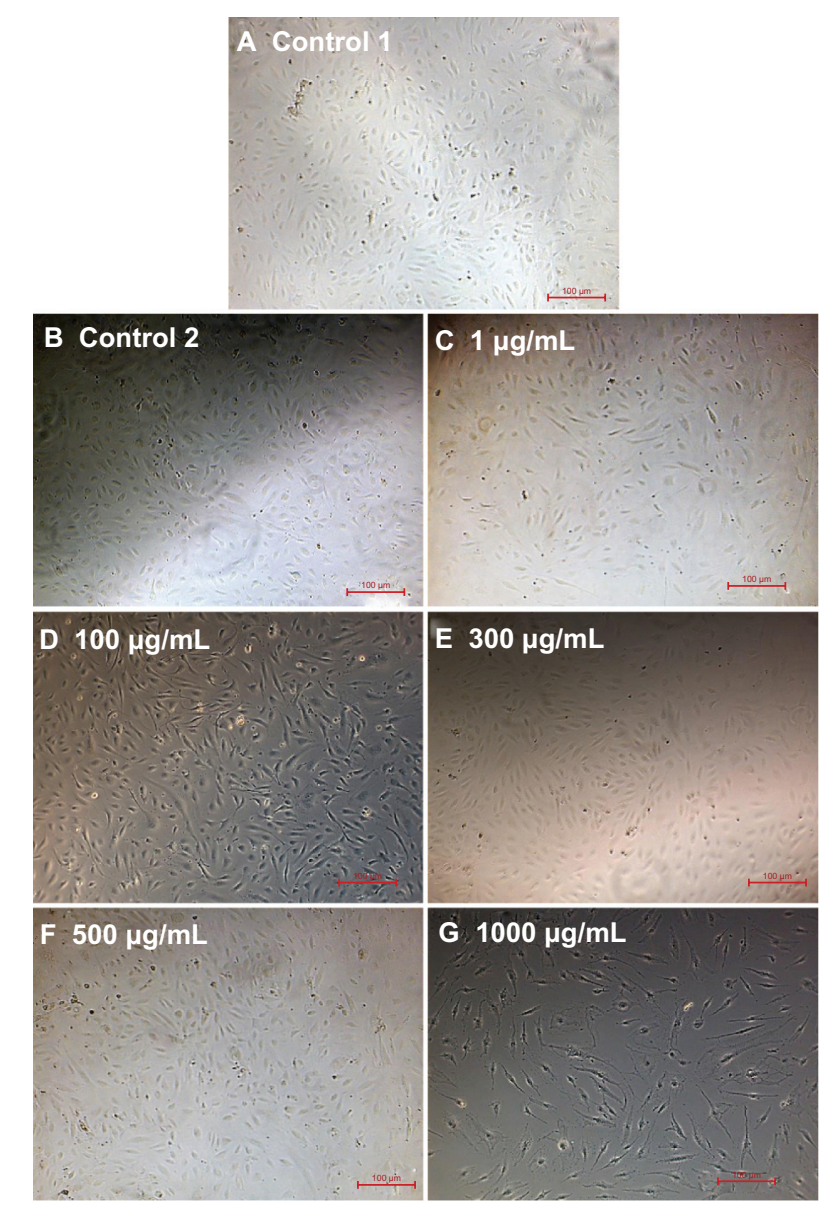

Figure 8 Phase contrast images of endothelial cells for the different doses of L-ascorbic acid (A-G)(scale bar indicates $100 \mu \mathrm{m}$ ).

\section{Morphology of SMCs for L-AA, SIR, PAT, and controls}

The phase contrast microscopy images taken after 7 days of cell growth for the different samples used in experimental set 3 are provided in Figure 12. SMCs showed spreading morphology with a characteristic spindle shape for all three controls (Figure 12A-C). For L-AA (Figure 12F), although the cells were spindle shaped, they were less spreading compared to controls. For SIR (Figure 12D) and PAT (Figure 12E), the cells were not spreading and only very few cells were spindle shaped with the remaining cells either triangular or irregularly shaped. These results suggested that the spreading of SMCs was affected by treating with L-AA, SIR, and PAT while the morphological features of cells were also affected by SIR and PAT treatments.

\section{Viability and proliferation of SMCs for different doses of L-AA and controls}

Figure 13 shows the SMC viability and proliferation for the five different doses $(1 \mu \mathrm{g}, 100 \mu \mathrm{g}, 300 \mu \mathrm{g}, 500 \mu \mathrm{g}$, and $1000 \mu \mathrm{g})$ of

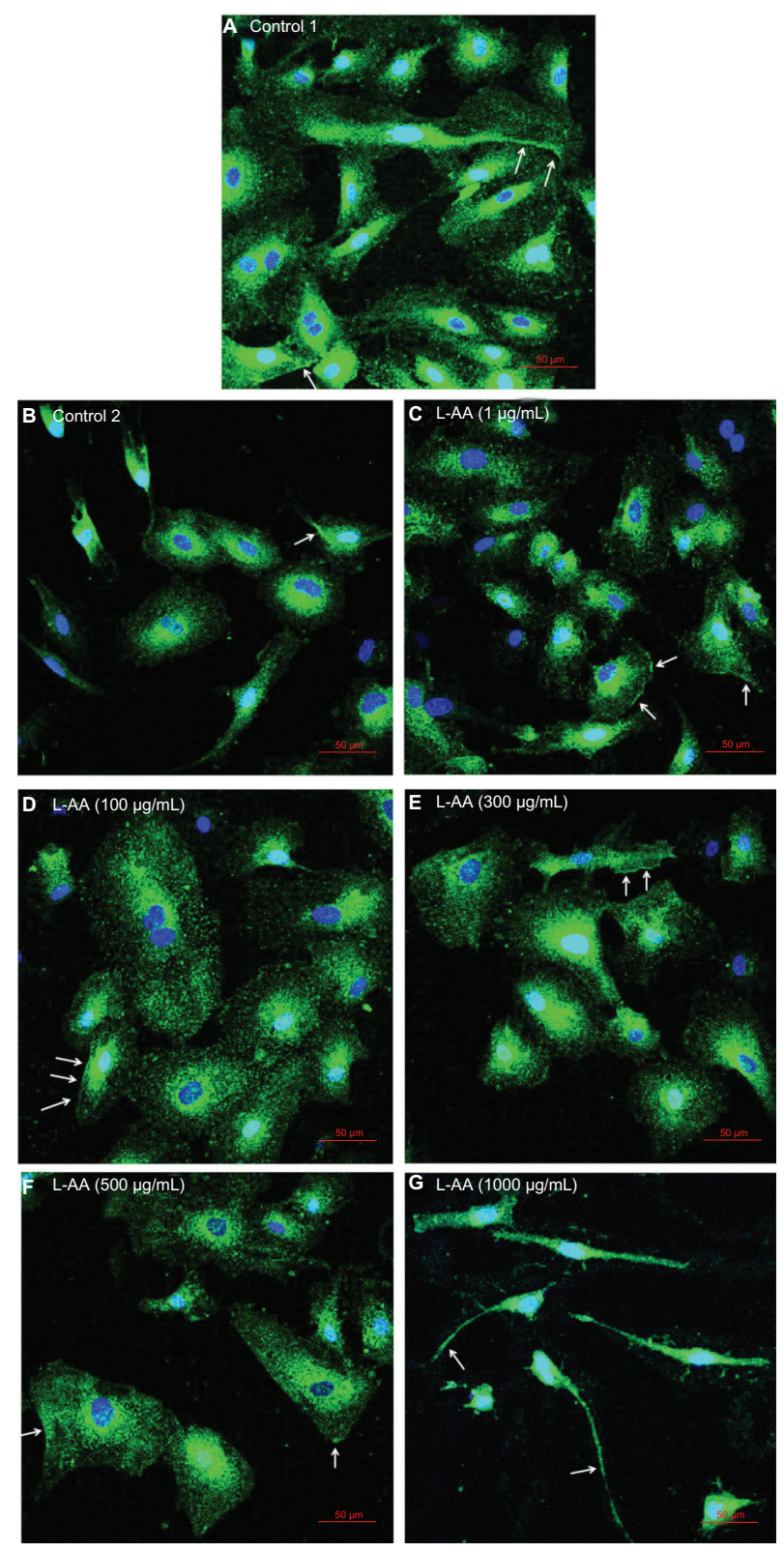

Figure 9 Immunofluorescence microscopy images of endothelial cells for different doses of L-AA (A-G) (scale bar indicates $50 \mu \mathrm{m}$ ).

Abbreviation: L-AA, L-ascorbic acid.

L-AA and the two controls of experimental set 4 . On day 1 , the L-AA doses ranging from $100 \mu \mathrm{g}$ to $1000 \mu \mathrm{g}$ showed significantly fewer cells than controls and $1 \mu \mathrm{g}$ L-AA dose. A similar trend was observed on day 3 . Also, the L-AA doses $500 \mu \mathrm{g}$ and $1000 \mu \mathrm{g}$ showed fewer cells than $100 \mu \mathrm{g}$ and $300 \mu \mathrm{g}$ L-AA doses on day 3. Similar results were observed on day 5 and day 7. Based on these results, the cell viability and proliferation decreased in the following order: Control $1=$ Control $2=$ $1 \mu \mathrm{g}>>100 \mu \mathrm{g}=300 \mu \mathrm{g}>500 \mu \mathrm{g}=1000 \mu \mathrm{g}$.

The fluorescence microscopy images of FDA-stained SMCs for the different doses of L-AA and the controls used 


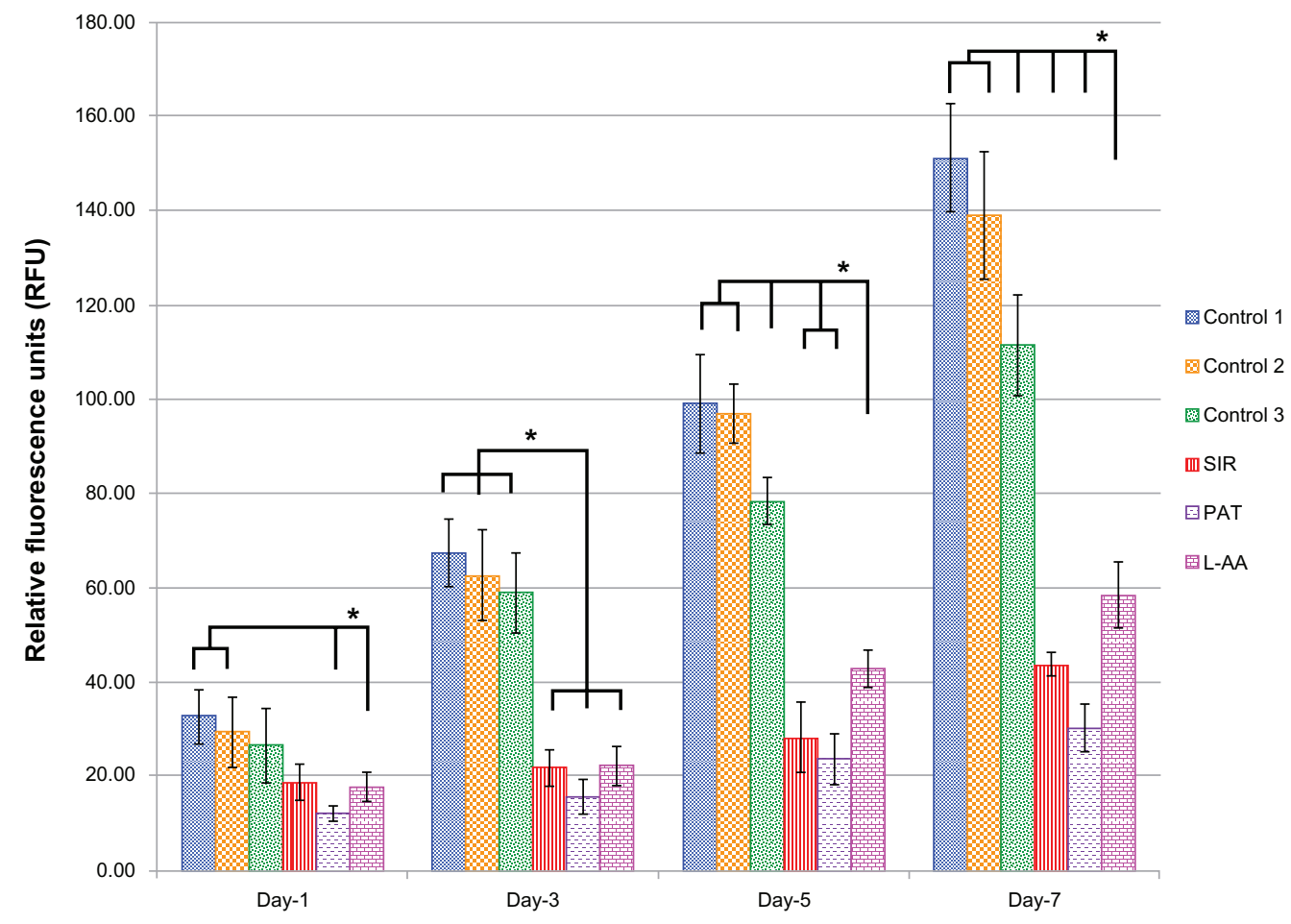

Figure 10 Smooth muscle cell viability and proliferation for L-AA, SIR, PAT, and controls.

Notes: * denotes statistical significant differences at $p<0.05$.

Abbreviations: L-AA, L-ascorbic acid; PAT, paclitaxel; SIR, sirolimus.

in the experimental set 4 are provided in Figure 14. These images showed that cells were proliferating significantly for the two controls and the $1 \mu \mathrm{g}$ L-AA dose from one time point to the other, while cell growth was significantly inhibited for the L-AA doses ranging from $100 \mu \mathrm{g}$ to $1000 \mu \mathrm{g}$. After 7 days, all the controls and $1 \mu \mathrm{g}$ L-AA dose showed $>90 \%$ confluence while the $100 \mu \mathrm{g}$ and $300 \mu \mathrm{g}$ L-AA doses showed $50 \%-60 \%$ confluence, and the $500 \mu \mathrm{g}$ and $1000 \mu \mathrm{g}$ L-AA doses showed $30 \%-40 \%$ confluence. Thus, these results demonstrated that L-AA showed a dose dependent inhibitory effect, with $1 \mu \mathrm{g}$ dose showing no inhibitory effect and $1000 \mu \mathrm{g}$ dose showing maximum inhibitory effect.

\section{Morphology of SMCs for different doses of L-AA and controls}

The phase contrast microscopy images of SMCs after 7 days of growth for the different doses of L-AA and controls are provided in Figure 15. The two controls (Figure 15A and B) and the $1 \mu \mathrm{g} \mathrm{L}$-AA dose (Figure 15C) showed spreading morphology with its characteristic spindle shape. In $100 \mu \mathrm{g}$ and $300 \mu \mathrm{g}$ L-AA doses (Figure 15D and E), although the cells were spindle shaped, they were not as spreading as the controls. For $500 \mu \mathrm{g}$ and $1000 \mu \mathrm{g}$ L-AA doses (Figure 15F and G), the cells were not spreading and the shapes were too elongated.
These results suggested that the high L-AA doses affect the spreading and morphological features of SMCs.

\section{Discussion}

The antiproliferative drugs (SIR and PAT) released from stents and vascular grafts inhibit the growth of SMCs and thereby prevent neointimal hyperplasia. ${ }^{7,14}$ The mechanisms of action of SIR and PAT on cells are different. SIR is cytostatic (inhibits cell growth and division) while PAT is cytotoxic (toxic to cells). Several studies in the literature have demonstrated the mechanisms of action of these drugs. ${ }^{20,21}$ Specifically, SIR is an immunosuppressive agent which works by binding to an intracellular receptor protein FKBP12 and causes cell cycle arrest. ${ }^{20}$ However, PAT is a mitotic inhibitor which works by interfering with the normal breakdown of microtubules during cell division and inhibits cell growth. ${ }^{21}$ These drugs are not cell specific. Hence, the growth of endothelial cells on stents and vascular grafts has also been inhibited by the same mechanism..$^{10,13}$ This is a serious concern since the poorly endothelialized device surfaces can cause thrombosis. ${ }^{11}$ Hence, there is a great need to use alternative drugs in these medical devices to promote ECs, and inhibit SMCs, to prevent thrombosis and neointimal hyperplasia, respectively. Vitamin C (L-AA) has 


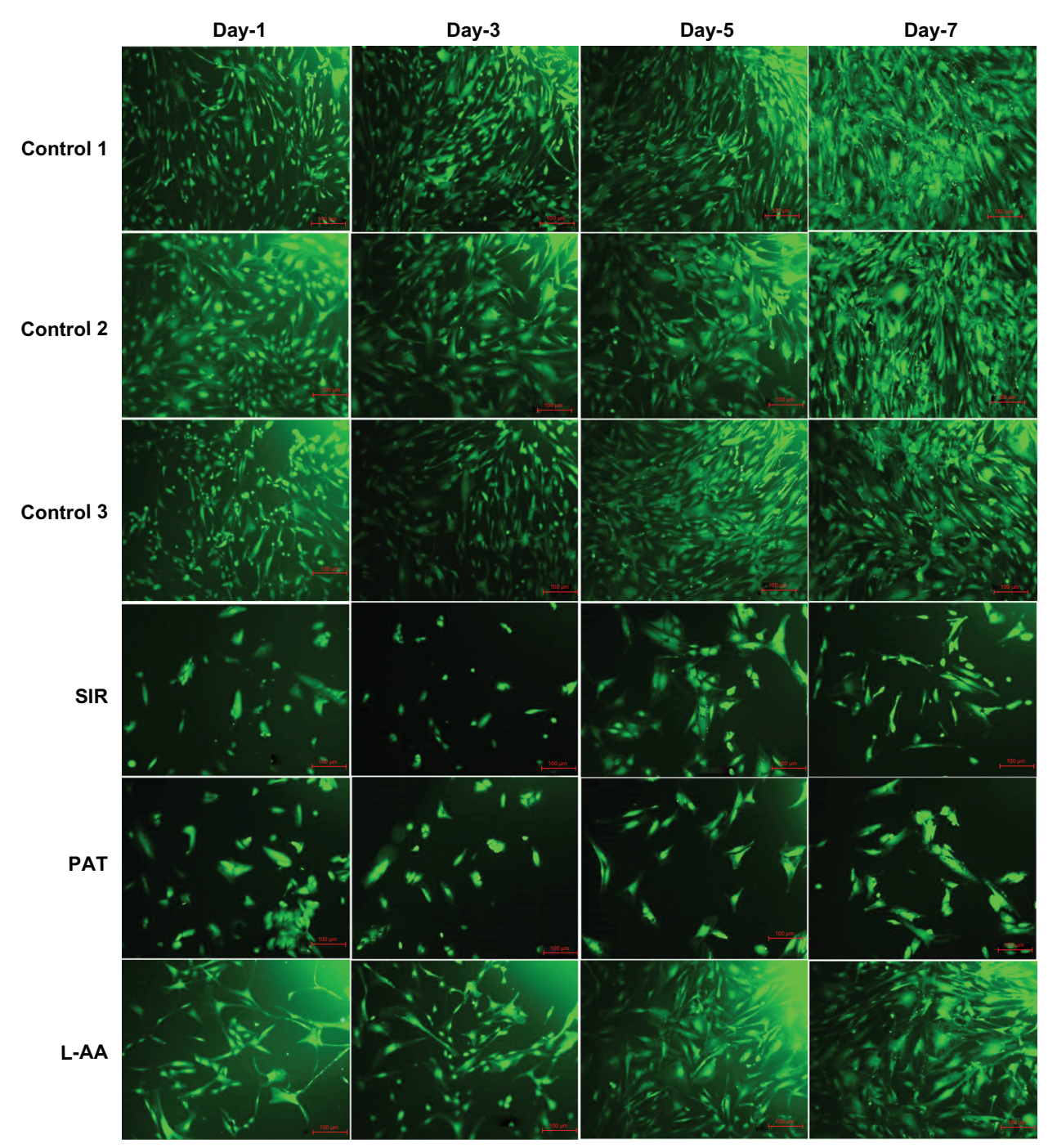

Figure I I Fluorescence microscopy images of FDA stained SMCs for L-AA, SIR, PAT, and controls (scale bar indicates I00 $\mu$ m). Abbreviations: FDA, fluorescein diacetate; L-AA, L-ascorbic acid; PAT, paclitaxel; SIR, sirolimus; SMCs, smooth muscle cells.

been shown to promote $\mathrm{ECs}^{22-24}$ and inhibit $\mathrm{SMCs}^{16,23,25}$ when orally administered or added directly to the cell cultures. ${ }^{15,16}$ Although vitamin $\mathrm{C}$ has such beneficial properties, to the best of our knowledge, it has not yet been used in stents or vascular grafts since the need to deliver a drug to encourage EC growth, and inhibit SMC growth, has arisen recently.

The proliferative effect of L-AA on ECs is due to its prominent role in synthesizing type IV collagen, which is required for the formation of basement membrane (where the ECs rest) and the regulation of EC adhesion. ${ }^{26}$ L-AA significantly decreased the apoptosis of ECs under inflammatory conditions. ${ }^{27}$ This effect arises from L-AA's role in inhibiting cytochrome $\mathrm{C}$ release from mitochondria and preventing caspase 9 activation. ${ }^{16}$ Also, L-AA increased the generation of nitric oxide by stabilizing tetrahydrobiopterin, a co-factor involved in nitric oxide production by nitric oxide synthases. ${ }^{28}$
This has an effect not only in maintaining healthy EC function but also reducing oxidative stress and inflammation in the entire vessel wall. Several clinical trials have shown that the systemic administration of L-AA has reversed endothelial cell dysfunction caused by hypercholesterolemia, diabetes, and atherosclerosis. ${ }^{15,29,30}$ L-AA has been shown to inhibit the proliferation of SMCs. ${ }^{16,23}$ The antiproliferative effect of L-AA on SMCs is due to the inhibition of membranous tyrosine kinase protein ${ }^{31}$ and reduction of L-cysteine transport and cellular glutathione levels. ${ }^{23,25}$ In addition to encouraging EC growth and inhibiting SMC growth, L-AA has been shown to inhibit the adhesion and aggregation of blood platelets, ${ }^{32}$ which is crucial for preventing thrombosis.

In this research, a comparative study was conducted to investigate the effects of L-AA, SIR, and PAT on the growth of ECs and SMCs under similar conditions. 


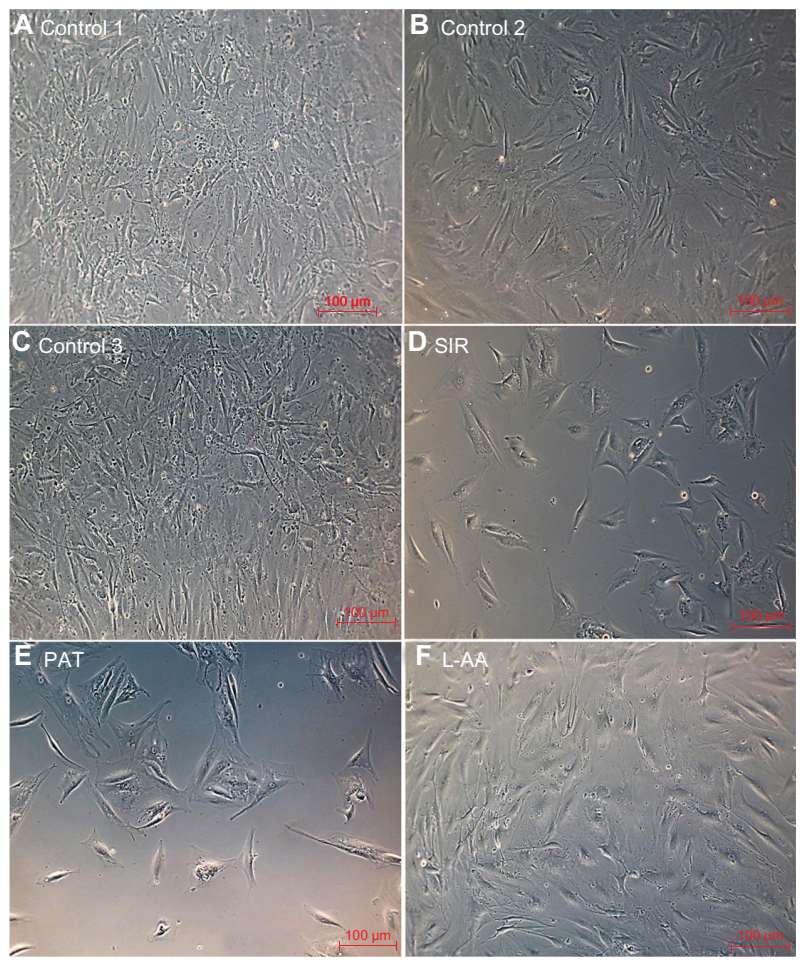

Figure 12 Phase contrast images of SMCs for L-AA, SIR, PAT, and controls (A-F) (scale bar indicates $100 \mu \mathrm{m}$ ).

Abbreviations: L-AA, L-ascorbic acid; SIR, sirolimus; SMCs, smooth muscle cells; PAT, paclitaxel.
A dose of $100 \mu \mathrm{g}$ was chosen for all the different drugs used in experimental sets 1 and 3 due to the following reasons. A drug concentration of $100 \mu \mathrm{g} / \mathrm{cm}^{2}$ is commonly used for PAT-eluting stents, ${ }^{7}$ which provides a total drug dose of $50 \mu \mathrm{g}$ to $209 \mu \mathrm{g}$ per stent depending on the stent size..$^{33}$ Similarly, a drug concentration of $140 \mu \mathrm{g} / \mathrm{cm}^{2}$ is commonly used for SIReluting stents, ${ }^{7}$ which provides a total drug dose of $71 \mu \mathrm{g}$ to $314 \mu \mathrm{g}$ per stent depending on the stent size. ${ }^{33}$ Hence, a dose of $100 \mu \mathrm{g}$ was considered clinically relevant and used in this study. At this dose, both the antiproliferative drugs, SIR and PAT, significantly inhibited the growth of ECs. This clearly shows the role of these drugs in impairing endothelialization. However, L-AA significantly encouraged the growth of ECs even more strongly than the controls (with no drugs). Also, at this dose, L-AA significantly inhibited the growth of SMCs. Thus, this study demonstrates the use of L-AA over SIR and PAT for potential applications in stents and vascular grafts.

For experimental set 2, the different doses of L-AA including $1 \mu \mathrm{g}(5.7 \mu \mathrm{M}), 100 \mu \mathrm{g}(567.8 \mu \mathrm{M}), 300 \mu \mathrm{g}$ $(1.7 \mathrm{mM}), 500 \mu \mathrm{g}(2.8 \mathrm{mM})$, and $1000 \mu \mathrm{g}(5.7 \mathrm{mM})$ were compared to determine which dose shows maximum EC growth. The typical plasma concentration of L-AA in humans ranges between $37 \mu \mathrm{M}$ and $121 \mu \mathrm{M} .{ }^{22} \mathrm{~A}$ plasma concentration

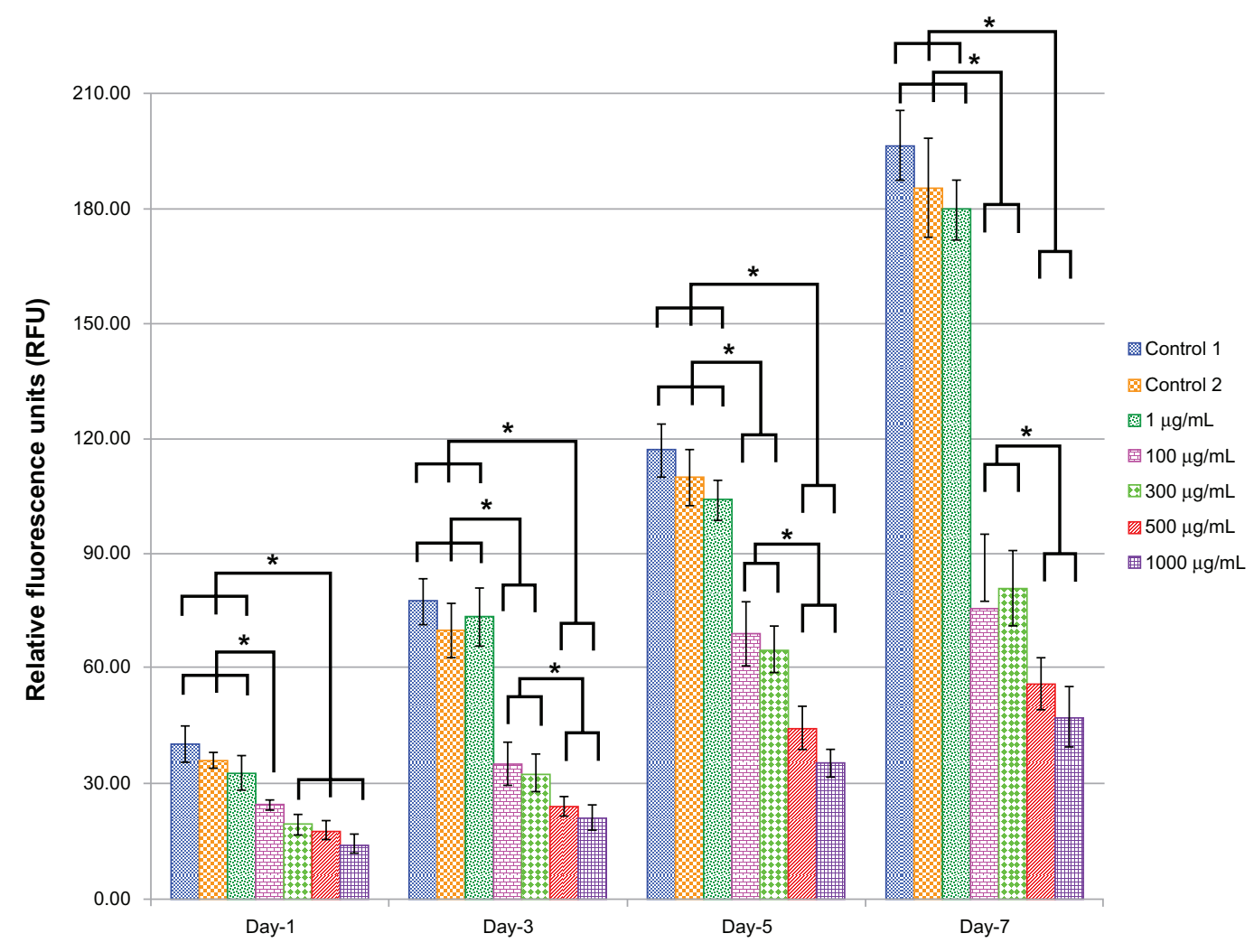

Figure 13 Smooth muscle cell viability and proliferation for the different doses of L-ascorbic acid. Notes: $*$ denotes statistical significant differences at $p<0.05$. 


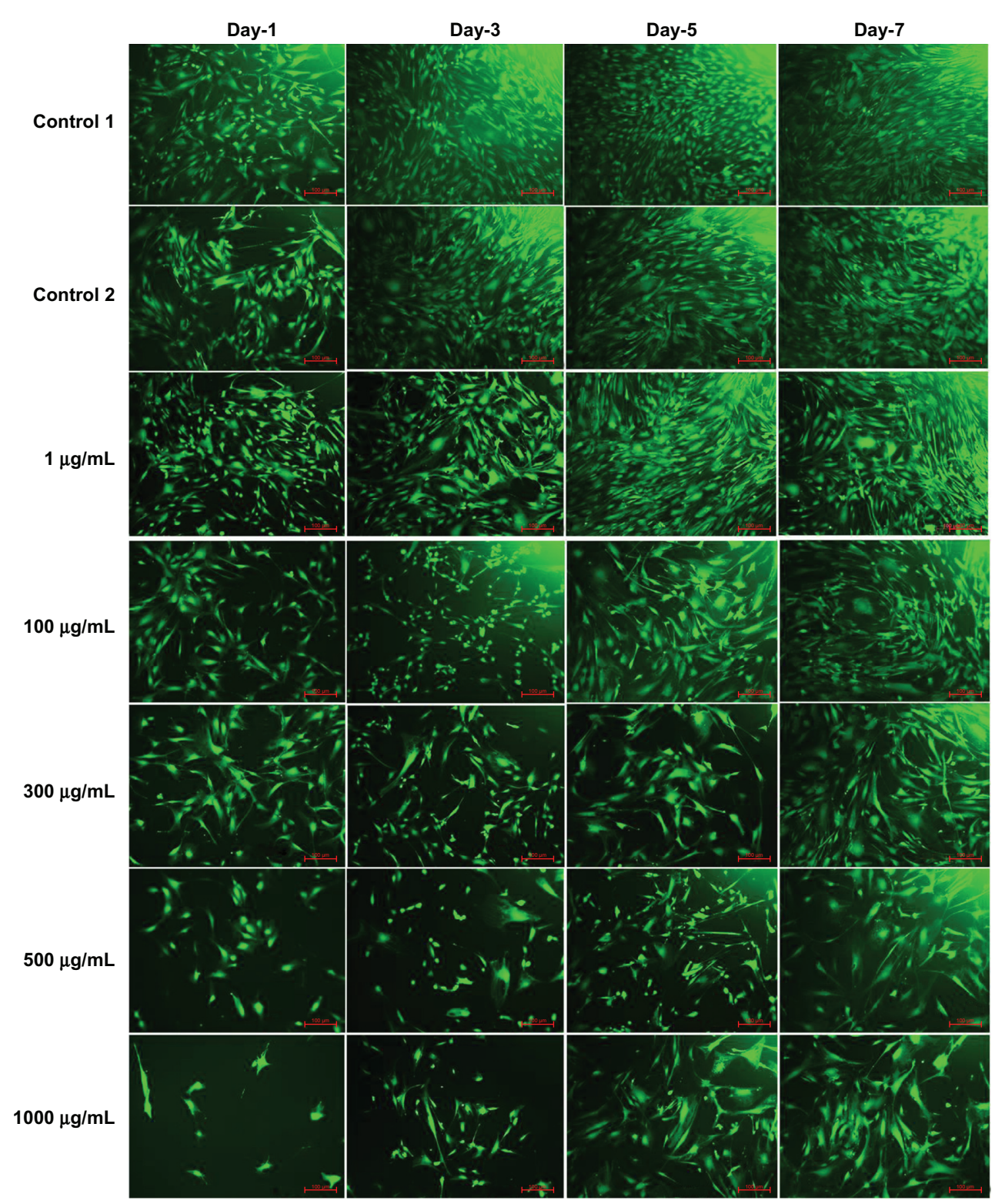

Figure I 4 Fluorescence microscopy images of fluorescein diacetate-stained smooth muscle cells for the different doses of L-ascorbic acid (scale bar indicates I00 $\mu \mathrm{m}$ ).

of $\geq 70 \mu \mathrm{M}$ of L-AA has been recommended for preventing coronary artery disease. ${ }^{34}$ Ulrich-Merzenich et a ${ }^{22}$ showed that when a dose of $\geq 60 \mu \mathrm{M}$ of L-AA was added directly to the EC cultures, the drug acted as a mitogen and greatly encouraged the growth of cells. Similarly, Smith et al ${ }^{24}$ showed a dose of $100 \mu \mathrm{M}$ of L-AA significantly encourage the growth of ECs. However, Bowie and O'Neill ${ }^{35}$ showed that a higher dose of $5 \mathrm{mM}$ to $20 \mathrm{mM}$ of L-AA has an inhibitory effect on ECs. These studies showed the importance of choosing the right dose of L-AA for promoting EC growth. Hence, in this study, the L-AA doses ranging from $1 \mu \mathrm{g}$ $(5.7 \mu \mathrm{M})$ to $1000 \mu \mathrm{g}(5.7 \mathrm{mM})$ were compared to determine the optimal dose for effectively encouraging EC growth as well as inhibiting SMC growth. A low dose of $1 \mu \mathrm{g}$ did not have a significant effect on EC or SMC growth as there was no difference observed when compared to that of the controls. A high dose of $1000 \mu \mathrm{g}$ had a maximum inhibitory effect on SMCs, but this dose also had an inhibitory effect on ECs. Among the intermediate doses, $100 \mu \mathrm{g}$ and $300 \mu \mathrm{g}$ showed maximum EC growth after 7 days. Also, these doses significantly inhibited SMC growth. Hence, a dose of $100 \mu \mathrm{g}$ $(567.8 \mu \mathrm{M})$ to $300 \mu \mathrm{g}(1.7 \mathrm{mM})$ can be coated on cardiovascular medical devices to improve their endothelialization properties. Our future studies involve the coating of these optimized L-AA doses on stents and vascular grafts and studying their endothelialization properties. 


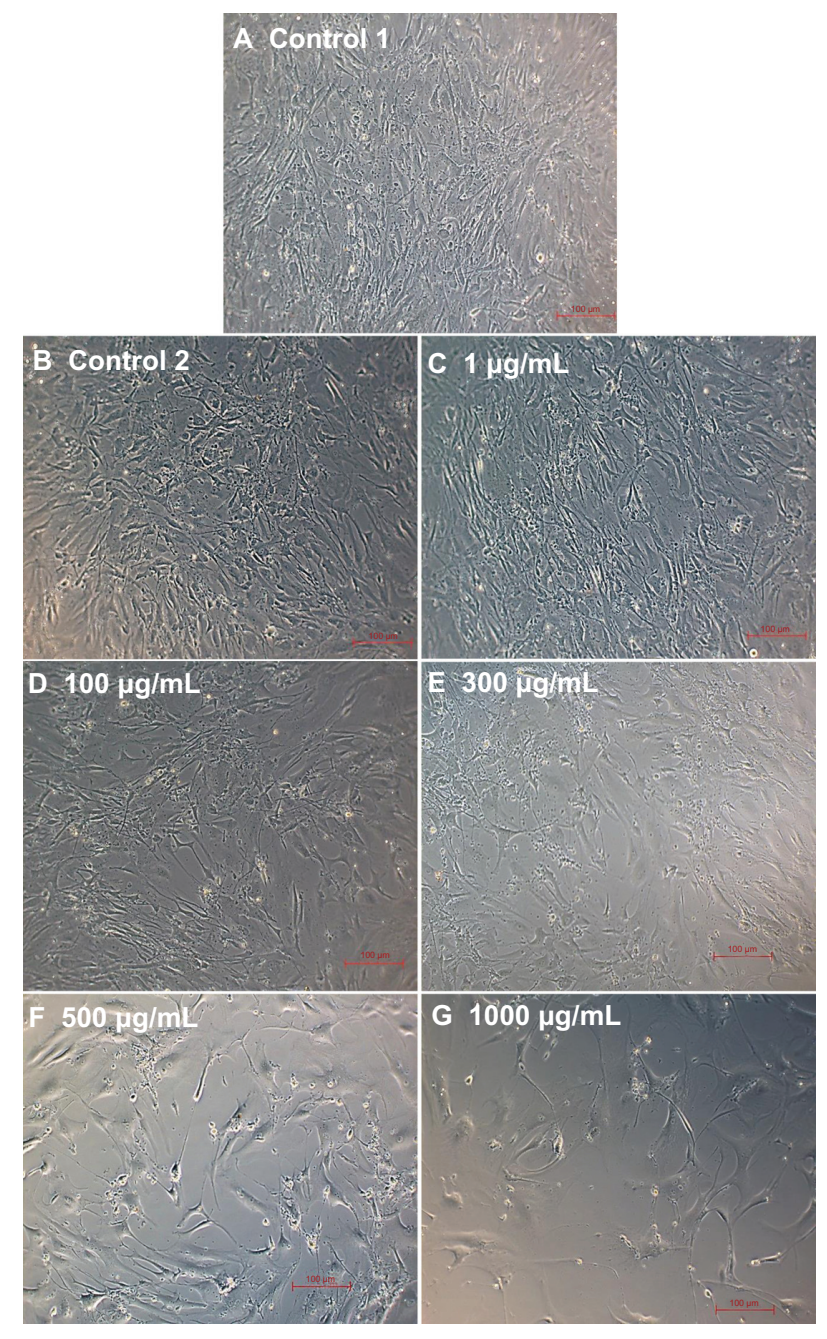

Figure 15 Phase contrast images of smooth muscle cells for the different doses of L-ascorbic acid (A-G) (scale bar indicates $100 \mu \mathrm{m}$ ).

\section{Conclusion}

A comparative study was carried out to determine the effects of L-AA, SIR, and PAT on the growth of ECs and SMCs under similar conditions. Both SIR and PAT strongly inhibited EC growth while L-AA strongly encouraged EC growth. Also, L-AA significantly inhibited SMC growth although the inhibitory effect was inferior to SIR and PAT. A study of L-AA dosages showed that $100 \mu \mathrm{g}$ and $300 \mu \mathrm{g}$ doses promoted maximum EC growth when compared to the other doses $(1 \mu \mathrm{g}, 500 \mu \mathrm{g}$, and $1000 \mu \mathrm{g})$ and the controls used in the study. Also, the $100 \mu \mathrm{g}$ and $300 \mu \mathrm{g} \mathrm{L-AA}$ doses significantly inhibited the growth of SMCs. Thus, this study demonstrates the use of L-AA over SIR and PAT for potential applications in stents and vascular grafts.

\section{Disclosure}

The authors report no conflicts of interest in this work.

\section{References}

1. Mani G, Feldman MD, Patel D, Agrawal CM. Coronary stents: a materials perspective. Biomaterials. 2007;28(9):1689-1710.

2. Kannan RY, Salacinski HJ, Butler PE, Hamilton G, Seifalian AM. Current status of prosthetic bypass grafts: a review. $J$ Biomed Mater Res B Appl Biomater. 2005;74(1):570-581.

3. Ratner BD. The catastrophe revisited: blood compatibility in the 21 st Century. Biomaterials. 2007;28(34):5144-5147.

4. Wu KK, Thiagarajan P. Role of endothelium in thrombosis and hemostasis. Аnпu Rev Med. 1996;47:315-331.

5. Werner C, Maitz MF, Sperling C. Current strategies towards hemocompatible coatings. J Mater Chem. 2007;17:3376-3384.

6. Kapadia MR, Popowich DA, Kibbe MR. Modified prosthetic vascular conduits. Circulation. 2008;117(14):1873-1882.

7. Garg S, Serruys PW. Coronary stents current status. J Am Coll Cardiol. 2010;56(10):S1-S42.

8. Kipshidze N, Dangas G, Tsapenko M, et al. Role of the endothelium in modulating neointimal formation: vasculoprotective approaches to attenuate restenosis after percutaneous coronary interventions. $J$ Am Coll Cardiol. 2004;44(4):733-739.

9. Newby AC, Zaltsman AB. Molecular mechanisms in intimal hyperplasia. J Pathol. 2000;190:300-309.

10. Joner M, Nakazawa G, Finn AV, et al. Endothelial cell recovery between comparator polymer-based drug-eluting stents. J Am Coll Cardiol. 2008;52(5):333-342.

11. Finn AV, Nakazawa G, Joner M, et al. Vascular responses to drug eluting stents: importance of delayed healing. Arterioscler Thromb Vasc Biol. 2007;27(7):1500-1510.

12. Pilgrim T, Windecker S. Drug-eluting stent thrombosis. Minerva Cardioangiol. 2009;57(5):611-620.

13. Innocente F, Mandracchia D, Pektok E, et al. Paclitaxel-eluting biodegradable synthetic vascular prostheses: a step towards reduction of neointima formation? Circulation. 2009;120(Suppl 11):S37-S45.

14. Baek I, Bai CZ, Hwang J, Nam HY, Park JS, Kim DJ. Paclitaxel coating of the luminal surface of hemodialysis grafts with effective suppression of neointimal hyperplasia. J Vasc Surg. 2012;55(3):806-814.

15. Aguirre R, May JM. Inflammation in the vascular bed: importance of vitamin C. Pharmacol Ther. 2008;119:96-103.

16. Farbstein D, Kozak-Blickstein A, Levy AP. Antioxidant vitamins and their use in preventing cardiovascular disease. Molecules. 2010;15:8098-8110.

17. Ma Z, Kotaki M, Yong T, He W, Ramakrishna S. Surface engineering of electrospun polyethylene terephthalate (PET) nanofibers towards development of a new material for blood vessel engineering. Biomaterials. 2005;26(15):2527-2536.

18. Granchi D, Cenni E, Verri E, et al. Adhesive protein expression on human endothelial cells after in vitro contact with woven Dacron. Biomaterials. 1998;19(1-3):93-98.

19. Albelda SM, Muller WA, Buck CA, Newman PJ. Molecular and cellular properties of PECAM-1 (endoCAM/CD31): a novel vascular cell-cell adhesion molecule. J Cell Biol. 1991;114(5):1059-1068.

20. Marx S, Jayaraman T, Go L, Marks A. Rapamycin-FKBP inhibits cell cycle regulators of proliferation in vascular smooth muscle cells. Circulation Research. 1995;76(3):412-417.

21. Axel DI, Kunert W, Göggelmann C, et al. Paclitaxel inhibits arterial smooth muscle cell proliferation and migration in vitro and in vivo using local drug delivery. Circulation. 1997;96(2):636-645.

22. Ulrich-Merzenich G, Zeitler H, Panek D, Bokemeyer D, Vetter H. Vitamin C promotes human endothelial cell growth via the ERKsignaling pathway. Eur J Nutr. 2007;46(2):87-94.

23. Ulrich-Merzenich G, Metzner C, Schiermeyer B, Vetter H. Vitamin C and vitamin $\mathrm{E}$ antagonistically modulate human vascular endothelial and smooth muscle cell DNA synthesis and proliferation. Eur J Nutr. 2002;41:27-34.

24. Smith AR, Visioli F, Hagen TM. Vitamin C matters: increased oxidative stress in cultured human aortic endothelial cells without supplemental ascorbic acid. FASEB J. 2002;16(9):1102-1104. 
25. Siow RC, Sato H, Leake DS, Pearson JD, Bannai S, Mann GE. Vitamin $C$ protects human arterial smooth muscle cells against atherogenic lipoproteins: effects of antioxidant vitamins $\mathrm{C}$ and $\mathrm{E}$ on oxidized LDL-induced adaptive increases in cystine transport and glutathione. Arterioscler Thromb Vasc Biol. 1998;18:1662-1670.

26. Libby P, Aikawa M. Vitamin C, collagen, and cracks in the plaque. Circulation. 2002;105:1396-1398.

27. Rossig L, Hoffmann J, Hugel B, Mallat Z, Hasse A, Freyssinet JM. Vitamin $C$ inhibits endothelial cell apoptosis in congestive heart failure. Circulation. 2001;104:2182-2187.

28. Heller R, Unbehaun A, Schellenberg B, Mayer B, Werner-Felmayer G, Werner ER. L-ascorbic acid potentiates endothelial nitric oxide synthesis via a chemical stabilization of tetrahydrobiopterin. J Biol Chem. 2001;276:40-47.

29. Ting HH, Timimi FK, Haley EA, Roddy MA, Ganz P, Creager MA. Vitamin $\mathrm{C}$ improves endothelium-dependent vasodilation in forearm resistance vessels of humans with hypercholesterolemia. Circulation. 1997;95(12):2617-2622.
30. Gocke N, Keaney JF, Frei B, et al. Long-term ascorbic acid administration reverses endothelial vasomotor dysfunction in patients with coronary artery disease. Circulation. 1999;99:3234-3240.

31. Lu LH, Lee YT, Chen HW, Chiang LY, Huang HC. The possible mechanisms of the antiproliferative effect of fullerenol, polyhydroxylated C60, on vascular smooth muscle cells. Br J Pharmacol. 1998;123(6): 1097-1102.

32. Bordia A, Verma SK. Effect of vitamin C on platelet adhesiveness and platelet aggregation in coronary artery disease patients. Clin Cardiol. 1985;8:552-554.

33. Tsimikas $\mathrm{S}$. Drug-eluting stents and late adverse clinical outcomes lessons learned, lessons awaited. J Am Coll Cardiol. 2006;47(10):2112-2115.

34. Levine M, Dhariwal KR, Welch RW, Wang Y, JB. P. Determination of optimal vitamin C requirements in humans. Am J Clin Nutr. 1995; 62(Suppl 6):1347S-1356S.

35. Bowie AG, O'Neill LA. Vitamin C inhibits NF-kappa B activation by TNF via the activation of p38 mitogen-activated protein kinase. J Immunol. 2000;165(12):7180-7188.
Drug Design, Development and Therapy

\section{Publish your work in this journal}

Drug Design, Development and Therapy is an international, peerreviewed open-access journal that spans the spectrum of drug design and development through to clinical applications. Clinical outcomes, patient safety, and programs for the development and effective, safe, and sustained use of medicines are a feature of the journal, which

\section{Dovepress}

has also been accepted for indexing on PubMed Central. The manuscript management system is completely online and includes a very quick and fair peer-review system, which is all easy to use. Visit http://www.dovepress.com/testimonials.php to read real quotes from published authors.

Submit your manuscript here: http://www.dovepress.com/drug-design-development-and-therapy-journal 